
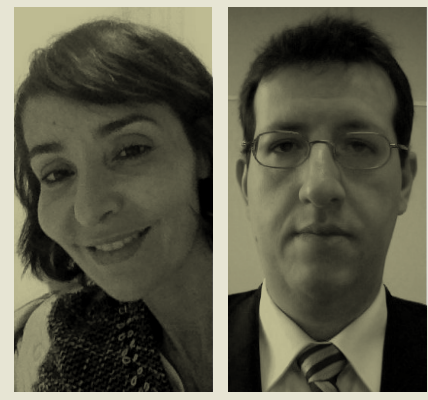

\title{
CONTRADIÇÕES DO PODER JUDICIÁRIO BRASILEIRO
}

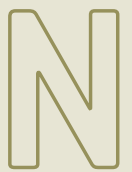

a mitologia grega, Sísifo é punido com uma tarefa sem sentido. Ele que, desafiando os deuses, enganara a morte, é condenado a empurrar montanha acima uma pedra. Ao fim, esta rolaria morro abaixo, e, mais uma vez, Sísifo se empenharia em levar a rocha ao topo. Isso se repetiria eternamente.

Para aquele que repete a tarefa, a falta de sentido advém da consciência de que o trabalho não altera a realidade e o resultado produzido não representa nenhuma melhora no mundo. Muitas vezes, o trabalho judicial, do ponto de vista de quem o faz, é tido como uma repetição do mito de Sísifo. Se, para o produtor, o serviço se mostra repetitivo e inócuo, para o cidadão o resultado é um trabalho moroso e pouco satisfatório. E é nesse ponto que se apresentam as propostas de tornar o sistema judicial mais eficiente: ele tem de atender melhor à expectativa do receptor. E, para torná-lo mais eficiente, é preciso reformá-lo. Mas como?

Compreendido entre o poder e o serviço, o Judiciário brasileiro sofre sua crise de maioridade democrática no século XXI. Da eficiência à participação popular, da produtividade ao acesso, das garantias aos custos, ele se equilibra precariamente na concepção individual da balança.

Dentre todos os pontos de atrito, pinça-se aqui a percepção do problema do conflito de agendas dos atores judiciários, elemento existente no sistema, mas pouco explorado.

Na primeira tentativa de reforma do Poder Judiciário, o grande objetivo foi buscar a ampliação da efici- ência, aumentando a velocidade dos processos. No entanto, sem negar a necessidade de profundas reavaliações dos procedimentos cartoriais, o desafio enfrentado é mais complexo do que aparenta.

Em teoria dos jogos, a atividade jurisdicional é o que se chama de jogo de soma zero, isto é, para um dos participantes vencer, necessariamente o outro perderá. E se, na teoria, as duas partes cooperam para alcançar o objetivo final, na realidade, na maioria das vezes, uma das partes está ciente de que o resultado lhes é desfavorável, investe contra a própria estrutura do jogo.

Embora seja essa a prática usual dos tribunais, pouco se explora a ideia do conflito inerente ao processo judicial, que redunda na resistência de uma, quando não de todas as partes envolvidas no produto final. $\mathrm{O}$ resultado do processo judicial, ao contrário da percepção inicial, não é querido ou desejado. Seu final é resistido intensamente.

A questão da eficiência do Judiciário tem uma face bastante clara do ponto de vista do produtor de serviço, pois a prestação deve ser feita. Mas também tem uma face pouco explorada: há interesses e ganhos por parte do cidadão com a morosidade, como quando este é apontado como réu ou devedor. Nessa posição, interessa a ele que o processo seja demorado e com muitos recursos.

É evidente que se deve melhorar o trabalho, tornando-o mais célere. No entanto, reduzir a questão da reforma do Judiciário unicamente à busca por rapidez encobre problemas mais profundos relacionados à cultura jurídica e à atuação dos profissionais do Direito. 